\title{
PERFORMANCE DETERMINANTS OF STATE CIVIL SERVICES (ASN) IN THE COVID-19 PANDEMIC
}

\author{
Siti Nurhusna ${ }^{1}$, Wahyudi ${ }^{2}$ \\ ${ }^{1}$ Universitas Muhammadiyah Jakarta, Indonesia \\ ${ }^{2}$ Universitas Pamulang, Indonesia \\ Email : sitinurhusna@gmail.com¹, tahfizz@gmail.com²
}

\begin{abstract}
ABSTRAK
Sejak Covid-19 mewabah pada bulan Mei 2020 telah terjadi pergeseran pola dan sistem kerja di berbagai instansi dan perusahaan, tidak terkecuali pemerintahan. Hal tersebut dilakukan sebagai bentuk adaptasi terhadap keadaan, khususnya di dalam mencegah penyebaran virus Covid-19. Namun di sisi lain organisasi harus tetap berjalan, oleh karenanya hadir model kerja work from home. Konsep ini hadir karena keadaan, sehingga berbagai kekurangan muncul, salah satunya aktivitas kerja tidak berjalan secara efektif dan berdampak menurunnya kinerja pegawai. Sejatinya, penelitian ini dilakukan untuk mengetahui fenomena tersebut, dan faktor apa saja yang memiliki linearitas terhadap kinerja pegawai. Metode penelitian yang digunakan di dalam menjawab hipotesis penelitian adalah kuantitatif dengan statistik regresi (peramalan). Sampel penelitian adalah pegawai BPPT yang berjumlah 80 orang, dengan teknik pengambilan sampel acak sederhana. Hasil penelitian merekomendasikan model yang paling baik meningkatkan kinerja selama masa pandemi adalah model simultan. Artinya, faktor-faktor yang berkaitan langsung dengan kinerja pegawai memiliki dampak yang besar terhadap peningkatan kinerja, di antaranya semangat kerja yang tinggi, beban kerja yang proporsional, dan keterbukaan karier. Dengan kata lain, institusi harus peka terhadap determinan kinerja, baik dalam keadaan normal ataupun pandemi.
\end{abstract}

Kata Kunci : Jenjang Karier, Beban Kerja, Semangat Kerja, Kinerja, Pegawai

\section{ABSTRACT}

Since the Covid-19 outbreak in May 2020 there has been a shift in work patterns and systems in various agencies and companies, including the government. This is done as a form of adaptation to the situation, especially in preventing the spread of the Covid-19 virus. But on the other hand the organization must continue to run, therefore there is a work from home work model. This concept exists because of circumstances, so that various shortcomings arise, one of which is work activities do not run effectively and have an impact on decreasing employee performance. In fact, this research was conducted to find out this phenomenon, and what factors have linearity on employee performance. The research method used in answering the research hypothesis is quantitative with statistical regression (forecasting). The research sample was BPPT employees totaling 80 people, with a simple random sampling technique. The results of the study recommend that the model that best improves performance during the pandemic is the simultaneous model. This means that factors directly related to employee performance have a major impact on improving performance, including high morale, proportional workload, and career openness. In other words, institutions must be sensitive to the determinants of performance, both under normal circumstances or in a pandemic.

Keywords: Careers, Workloads, Morale, Performance, Employee

\section{INTRODUCTION}

The success of a government institution is influenced by the performance of the State Civil Apparatus (ASN) or the work achieved by the State Civil Apparatus (ASN) in performing duties in accordance with the responsibilities given to him. As human 
resources in government organizations, the State Civil Apparatus (ASN) has a significant role in determining the success of national development, both physical and non-physical development. This shows that the State Civil Apparatus (ASN) is the backbone of the country, so that the national development goal of realizing a just and prosperous society based on Pancasila and the 1945 Constitution is largely determined by the implementation of the tasks assigned to the government apparatus.

Currently, all parts of the world are being hit by an outbreak of the COVID-19 virus, which is marked by the WHO's designation as a COVID-19 pandemic, on January 19,2021 , with the number of victims exposed to 31.6 million cases from 186 countries with a death toll of more than 971,000 people and patients recovering. more than 21.7 million people (source: WHO). Meanwhile, in Indonesia the COVID-19 outbreak has tested positive for COVID-19 as many as 927,380 with a death toll of 26,590 and patients recovering as many as 753,948 people (source: covid19.go.id).

With the Covid 19 pandemic situation, the DKI Jakarta government issued Governor Regulation Number 33 of 2020 regarding the implementation of "LargeScale Social Restrictions in Handling Corona Virus Disease 2019 (COVID-19) in the Special Capital Region of Jakarta" and Circular Letter (SE) of the Minister of PANRB Number 58 Year 2020 concerning the Work System of the State Civil Apparatus in the New Normal Order. In the MenPANRB regulation, this adjustment to the work system can be carried out through flexibility in setting work locations for State Civil Apparatuses (ASN), which includes carrying out official duties in the office (work from office); and/or Implementation of official duties at home/residence (work from home).

With regard to flexibility in setting work locations, the Personnel Guidance Officer is asked to arrange an accountable and selective work system for State Civil Apparatus (ASN) within the work unit who can carry out official duties in the office and/or at home/residence by taking into account the conditions of the spread of Covid1919 in their respective areas.

With the new normal work system regulations, it will gradually affect employee motivation where employees carry out many tasks at home rather than at the office. This will also have an impact on the workload that adapts to the new normal work system and has a major impact on the career development of the State Civil Apparatus (ASN) which will ultimately affect the performance of the State Civil Apparatus (ASN) and the performance of the Material Technology Center Work Unit (PTM). .

The workload of employees is a major factor in career development, and can support the achievement of organizational goals. During the Covid-19 pandemic, the implementation of workloads in government agencies or in companies experienced many changes in working hours where many government agencies and companies implemented a system of carrying out duties/services at home/WFH (Work From Home) in the long term which could affect directly on the workload. The application of the system for carrying out official duties at home is not limited to normal working hours, this is because working through an online system (online) so that work can be done anytime and anywhere without being constrained by place and time, meetings can also be held online, this is what This causes the working hours to be longer without being assessed for overtime.

The implementation of the work at home system can be hampered if the communication network is inadequate, this can affect the performance of employees in the Material Technology Center Work Unit (PTM) as well as the institutional performance of the Material Technology Center Work Unit (PTM). The workload during the Covid-19 pandemic also takes into account age, employees over the age of 60 are allowed to work at home for one full week.

The workload during the Covid-19 pandemic has undergone many changes, this has become a concern for the leadership in making policies related to workloads. A 
leader must assess and be wise in setting a proportional and fair workload [1]. Spinelli, et al. Explaining that excessive workloads can cause emotional disturbances for employees and have a negative impact on work productivity.

Based on the author's observations, the implementation of a new work system in the midst of the COVID-19 pandemic has created new dynamics in the work culture. Employees at the Material Technology Center Work Unit (PTM) carrying out official duties at home for a long time will make them lazy to come to the office which ultimately affects employee motivation [2,3].

The Material Technology Center Work Unit (PTM) currently carries out many Budget Execution List (DIPA) and Non-DIPA activities, namely the activities of the Education Fund Management Institute (LPDP) and has implemented SNI ISO/IEC 17025-2018 Quality System Management for laboratory services. testing, it will have an effect on increasing the workload which causes disproportionate between carrying out routine tasks of activities or working on testing services. With the increasing number of jobs being carried out during the COVID-19 pandemic, employees at the Material Technology Center Work Unit (PTM) have to adapt in managing their working time at home and doing it online (online).

Doing official duties at home is not an easy job because you have to divide your time between family time and work time, at the same time the learning process of school children is also carried out at home. This makes employees at the Material Technology Center Work Unit (PTM) unmotivated to do office tasks, especially when there are a lot of tasks to do and lack of supervision from the leadership due to a high sense of tolerance during the COVID-19 pandemic.

The author's observations continue on the workload, the work of the Budget Implementation List (DIPA) and Non-DIPA activities, namely the activities of the Education Fund Management Institution (LPDP) are tasks that must be completed on time according to the targets and targets set in the contract and constitute PENKIN ( Performance Determination) Material Technology Center Work Unit (PTM) as outlined in the 2021 BPPT Strategic Plan and testing service work. The workload assigned to the Material Technology Center Work Unit (PTM) employees is not all employees in the Material Technology Center Work Unit (PTM) equally, this is due to the level of education, competence/skills and age of the employee.

The author's observation continues on employee career development which can be influenced by motivation and workload, career development in question is a functional position. The problem faced by employees at the Material Technology Center Work Unit (PTM) in their career development is the decrease in motivation in collecting credit points this can be caused by the disproportionate workload they have such as the role/position in the STKK (Engineering Work Procedure) of the employee's activities. .

Another problem is the supporting facilities in the form of computers for employees who are not good, many of the computers owned are outdated, so that it can hamper the performance of employees in the Material Technology Center Work Unit (PTM). Problems in testing services are found in some test equipment that is damaged and has not been calibrated by the National Calibration Institute (KAN), this can hamper the process of testing services. List of test laboratory equipment at the Center for Material Technology

\section{BASIS THEORY}

The success or failure of an organization will be determined by Human Resources $(\mathrm{HR})$, an employee who has good work performance can support the achievement of goals and objectives set by the organization. Experts explain, HR is the main element 
in an organization [4]. The element in question, that $\mathrm{HR}$ is a factor that runs and revives organizational activities [5].

In this process the management function has a very important role in determining the implementation of the organization, as it is known that employees are ordinary people who have certain desires that are expected to be fulfilled by the organization where they work [6]. On the other hand, the organization also wants its employees to innovate and be efficient in terms of work that is sustainable and the result is a process to be effective and efficient [7]. Therefore, performance is present as a measure for both parties.

Definitively, performance is the main instrument of organizational success, on the other hand performance is the expectation of employees in getting their rights [8]. In practice, performance is influenced by many factors, including work motivation. According to experts, work enthusiasm is a desire that encourages someone to do something $[9,10]$. However, emotionally the desire or spirit is born because of a stimulus, such as compensation. In the concept of work, motivation is needed so that the implementation of tasks runs smoothly and has a positive impact on a comfortable working atmosphere [11].

Another factor that affects performance is workload. Experts assert, workload includes negative variables that have a negative impact on employee performance [12]. Therefore, this factor needs to be anticipated, so as not to have a major effect on the overall state of the organization's work environment [13]. Therefore, organizations need to present a proportional division of tasks, provide work guidelines or procedures, set targets, and establish disciplinary provisions. With these instruments, it is expected to reduce the workload [14]. In addition, the organization must support the formation of a harmonious work environment. Often the workload occurs because of a mismatch between one employee and another. In many studies, workload is a factor that has a significant effect on performance decline.

In addition to workload, career path is considered to have an influence on an employee's performance [15]. The reason is, a career is a stimulus that can directly increase enthusiasm at work, even with a career increase, an employee will show better work performance [16]. Theoretically a career is a promotion, but often in the form of an award. When someone shows good performance and other indicators are met, then the organization gives an award in the form of a promotion or an increase in income [17]. In a research it is explained, career is a performance indicator that is applied as an organizational strategy in achieving goals more effectively and efficiently. In practice, careers can create positive competition, where every employee will compete to show work performance.

\section{RESEARCH METHODS}

This study uses quantitative methods. The data used are primary data derived from respondents obtained from the results of the use of questionnaires in the form of structured statements that are qualified using ascale Likert. This study uses four variables, namely three variables as pure exogenous variables, namely: Motivation $\left(\mathrm{X}_{1}\right)$, Workload $\left(\mathrm{X}_{2}\right)$, Career Development $\left(\mathrm{X}_{3}\right)$ and the endogenous variable is Employee Performance $(\mathrm{Y})$. 
The sample in this study were employees at the Agency for the Assessment and Application of Technology (BPPT) as many as 80 people. In the retrieval, a simple random technique was used. The method of analysis using the approach of linear regression through the following steps:

1. Validity test

2. Reliability test

3. Feasibility test

4. Partial test

5. Simultaneous test

6. Determinant test

\section{RESULTS AND DISCUSSION}

Descriptive Analysis

1. Based on the results of questionnaires to the variable Motivation can be concluded that the motivation weighs least of which is the dimension Social Needs with the lowest average score of 2.45 is in the bad category. In other words, if the problem is identified that the coordination between employees is not good, it is better for the BPPT leadership to have good communication skills to keep their team motivated and coordinated.

2. The results of distributing questionnaires for the Workload variable can be concluded that the smallest weight is the Task Demand Factor dimension with the lowest average value of 2.31 in the bad category. This means that the problem is identified that employees are still sorting and choosing jobs, so the BPPT Work Unit should pay more attention to work assignments that are in accordance with the field of work and career plans of employees so that employees can complete work on time.

3. The results of distributing questionnaires for the Career Development variable can be concluded that the smallest weight is the Fate Factor dimension with the lowest average value of 2.31, which is in the bad category. In other words, if the problem is identified that career development is hampered due to the work system applied at home, it is advisable that the Material Technology Center Work Unit - BPPT should encourage employees to participate in self-assessment and help them determine realistic career paths by providing coaching through training and the like. so that they remain productive in working at home during the current covid-19 pandemic.

4. The results of distributing questionnaires for the Employee Performance variable, it can be concluded that the Employee Performance in the Material Technology Center Work Unit - BPPT has the smallest weight in statement 3 "With the computer being obsolete, I still take the initiative in carrying out work tasks correctly", which is in the "Initiative" dimension with the lowest average value of 2.35 , this value on a scale range of $1.80-2.59$ is categorized as not good, it can be said that a problem has been identified that many computers that are owned are outdated, thus hampering performance. employees, so that problems in testing services are found in some of the testing equipment that is damaged and has not been calibrated by the National Calibration Institute (KAN), this can hamper the process of testing services. Problems that come from employees or 
from the office will have a broad impact on employee performance which also affects the performance of the institution, so in improving employee performance it is better for the leadership of the Material Technology Center Work Unit - BPPT to provide a proper computer and good job facilitation so that the work can run smoothly. and effective.

\section{Partial Analysis}

1. Influence of motivation on employee performance.

The value of the intercept constant of 21,780 states that if the motivation variable increases by 1 unit, then the employee performance variable will increase by 21,780. The regression coefficient value of the Motivation variable on the Employee Performance variable is 0.601 . This means that if the Motivation variable increases by 1 unit, it will increase the Employee Performance variable by 0.601 , assuming the Motivation variable is considered constant. The results of this study are supported by the theory put forward by Maslow, that providing motivation to employees means that it will give employees encouragement to mobilize their abilities, expertise, and skills in carrying out their duties and obligations or in other words will improve the performance of these employees. With a strong motivation within the employee, the employee's performance will be optimal in order to achieve the goal of meeting their needs. In conclusion, because motivation can affect performance, management should further improve managerial management in the organization and managers need to pay attention to employee performance in accordance with their respective fields with recognition of achievements and promotions so as to foster high employee motivation.

2. Effect of Workload on Employee Performance

The intercept constant value of 12,489 states that if the Workload variable increases by 1 unit, then the Employee Performance variable will increase by 12,489. The regression coefficient value of the Workload variable on the Employee Performance variable is 0.911 . This means that if the Workload variable increases by 1 unit, it will increase the Employee Performance variable by 0.911 , assuming the Workload variable is considered constant. This study is in accordance with previous researchers, suggesting that if the employee's ability is higher than the demands of the job, a feeling of boredom will arise. On the other hand, if the employee's ability is lower than the demands of the job, more fatigue will appear. The workload given to employees can be divided into three, namely the workload that meets the standards, the workload that is too high, and the workload that is too low. So it is expected to provide an effective workload, so that it can be seen to what extent employees can be given the maximum workload, and the extent of its influence on the organization itself.

3. Effect of Career Development on Employee Performance e

The intercept constant value of 13,964 states that if the Career Development variable increases by 1 unit, then the Employee Performance variable will increase by 13,964 . The regression coefficient value of the Career Development variable on the Employee Performance variable is 0.650 . This means that if the Career Development variable increases by 1 unit, it will increase the Employee Performance variable by 0.650 , assuming the Career Development variable is 
considered constant. This research is supported by a theory that explains that career development is the process of increasing individual work abilities that are achieved in order to achieve the desired career. According to this concept, careers are only focused on improving work ability. Meanwhile, this concept does not address stagnant careers and declining careers." So it is better what employees do by improving and increasing the effectiveness of the implementation of the work of workers so that they are more able to make the best contribution in realizing organizational goals.

\section{Simultaneous Analysis}

The results of the analysis obtained aF value $\mathrm{c}_{\text {calculated }}$ of 79.276 and a significant value of 0.000 , it can be said that motivation, workload and career development together have a significant effect on employee performance. While the $\mathrm{R}$ Square value is 0.758 , this shows that $75.8 \%$ of the Motivation variable, Workload variable and Career Development variable have a simultaneous contribution to the Employee Performance variable and the remaining $24.2 \%$ is explained by other factors.

This research is supported by a theory that explains that performance is strongly influenced by employee motivation. Therefore, to improve organizational performance, a high level of motivation is needed, with a high level of employee motivation, employee performance will increase, whereas if employee motivation is low, there will be a decrease in performance in the organization.

\section{CONCLUSIONS AND RECOMMENDATIONS}

Based on the results of the analysis and discussion in the previous chapter, the following conclusions can be drawn:

1. The proof that motivation has a significant effect on performance explains that in carrying out tasks it takes encouragement from within, so that the assigned tasks can be done properly and correctly. , and is worth the achievement.

2. The proof that workload affects performance decline explains that employees involve emotions in carrying out their duties, and emotions are very disturbed by work pressure, excessive working hours, irregular work patterns, high targets, and poor working relationships. All of these things directly adversely affect employee performance.

3. The proof that career development has a positive effect on performance means that an employee will work more optimally and consistently maintain his performance, if the career development system is implemented properly. In fact, not only increased performance, more than that, careers can maintain loyalty, commitment, and concern for the agency.

\section{REFERENCES}

[1] Spinelli, R., Magagnotti, N., \& Labelle, E. R. (2020). The effect of new silvicultural trends on mental workload of harvester operators. Croatian Journal of Forest Engineering: Journal for Theory and Application of Forestry Engineering, 41(2), 113.

[2] Galy, E. (2020). A multidimensional scale of mental workload evaluation based on Individual-Workload-Activity (IWA) model: validation and relationships with job satisfaction. Tutorials in Quantitative Methods for Psychology, 16, 240-252. 
[3] da Cruz Carvalho, A., Riana, I. G., \& Soares, A. D. C. (2020). Motivation on job satisfaction and employee performance. International Research Journal of Management, IT and Social Sciences, 7(5), 13-23.

[4] Harras, H., Sugiarti, E., \& Wahyudi, W. (2020). Kajian Manajemen Sumber Daya Manusia Untuk Mahasiswa.

[5] Anggraeni, F. N. (2020). DETERMINAN MOTIVASI INTERNAL TERHADAP KINERJA. SCIENTIFIC JOURNAL OF REFLECTION: Economic, Accounting, Management and Business, 3(2), 161-170.

[6] Rahmi, A., Achmad, G. N., \& Adhimursandi, D. (2020). The Effect of Leadership and Empowerment Style and Motivation on Work Discipline and Employee Performance in Sungai Kunjang Subdistrict, Samarinda City. International Journal of Business and Management Invention (IJBMI), 9(3), 8-14.

[7] Wahyu, W., \& Salam, R. (2020). KOMITMEN ORGANISASI (Kajian: Manajemen Sumber Daya Manusia).

[8] Wahyudi, M. (2019). PENGARUH DISIPLIN DAN MOTIVASI TERHADAP KINERJA KARYAWAN. SCIENTIFIC JOURNAL OF REFLECTION: Economic, Accounting, Management and Business, 2(3), 351-360.

[9] Anggraeni, F. N. (2020). SURVEY MOTIVASI KERJA DRIVER OJEK ONLINE GRAB. SCIENTIFIC JOURNAL OF REFLECTION: Economic, Accounting, Management and Business, 3(3), 251-260.

[10] Efendi, R., Rifa'i, M. N., Bahrun, K., Milla, H., \& Suharmi, S. (2020). The mediation of work motivation on the effects of work discipline and compensation on performance batik msmes employees in yogyakarta city, indonesia. International Journal of Multicultural and Multireligious Understanding, 7(1), 689-703.

[11] Purba, K., \& Sudibjo, K. (2020). The Effects Analysis of Transformational Leadership, Work Motivation and Compensation on Employee Performance in PT. Sago Nauli. Budapest International Research and Critics Institute (BIRCI-Journal): Humanities and Social Sciences, 3(3), 1606-1617.

[12] Rojas-Valverde, D., Gómez-Carmona, C. D., Oliva-Lozano, J. M., Ibáñez, S. J., \& Pino-Ortega, J. (2020). Quarter's external workload demands of basketball referees during a European youth congested-fixture tournament. International Journal of Performance Analysis in Sport, 20(3), 432-444.

[13] Kuijpers, E., Kooij, D. T., \& van Woerkom, M. (2020). Align your job with yourself: The relationship between a job crafting intervention and work engagement, and the role of workload. Journal of occupational health psychology, 25(1), 1.

[14] Creed, P. A., Kaya, M., \& Hood, M. (2020). Vocational identity and career progress: The intervening variables of career calling and willingness to compromise. Journal of Career Development, 47(2), 131-145.

[15] Chui, H., Li, H., \& Ngo, H. Y. (2020). Linking protean career orientation with career optimism: career adaptability and career decision self-efficacy as mediators. Journal of Career Development, 0894845320912526.

[16] Alvi, A. K., Jabeen, Z., Jawaid, A., \& Kaur, P. (2020). Relationship of Career Success and Organizational Performance Through the Path of Business Strategy. International Journal of Economics, Management and Accounting, 28(1), 1-33.

[17] Kong, H., Okumus, F., \& Bu, N. (2020). Linking organizational career management with Generation $\mathrm{Y}$ employees' organizational identity: The mediating effect of meeting career expectations. Journal of Hospitality Marketing \& Management, 29(2), 164-181. 